\title{
Korean Social Welfare Reform during the Economic Crisis"
}

\author{
Chanyong PARK \\ Department of Economics, \\ Andong Nationat University
}

This paper deals with the Korean welfare reform carried out due to the extremely unstable societal atmosphere, caused by the 1997 economic crisis. Introduction of the National Basic Livelihood Security Act and expansion of the coverage of social insurance are characterized as the projected reform. Neverthetess, the newly introduced public assistance program and the social insurance schemes still have room for improvement. For example, social insurance schemes had provided a protective umbrella in favor of regular workers, but it did not do the same for temporary contract-based workers or the self-enployed. The government's efforts have not been sufficient to overcome these problems. This paper suggests some measures to resolve problems still existing in the Korean welfare system today.

Keywords: public finance, income distribution, poverty, social insurance, social assistance

This work was financially supported by the World Bank under the project Pratuctive Welfore in Korea. Direcc all correspondence to Chanyong Park. Professor of Department of Economics. Andong National University 388 Songchon-Dong, Andong-Shi, Kyoungbuk 760-749, Korea; Tel: 82-54-820-5414; Email: parkch@andong.ac.kr, parkch@oskku.edu 


\section{INTRODUCTION}

A fter a long periad of rapid economic growth, Korea ran into serious economic to retain their competitiveness, leaving an unprecedentedly high rate of unemployment in the process. As shown in Table 1, the poverty ratios rose sharply from 7.67 percent in 1997 to 14.28 percent in 1998 due to the 1997 economic crisis. After the 1997 economic crisis, the government undertook various anti-poverty programs designed to ease the impact of mass lay-offs, including temporary livelihood protection for those rendered jobless. While overall household incomes shrank, households with lower income were most likely to see their income contract even further. Likewise, the situation worsened income distribution and pushed those at the bottom of the middle class down into the poverty class, widening the gap between the rich and the poor.

Table 1 displays the incidence of poverty in Korea, 1975-2001. The poverty line used in this study is set by the Korea Institute for Hcalth and Social Affairs (KIHASA) in 1994, and then adjusted by the Consumer Price Index (CPI) for the other years. It was measured by Rowntrec's Basic Needs Approach. The table shows a spectacular decline in absolute poverty ratio from 21.52 percent of urban households in 1975 co only 7.41 percent in 1996 . However, the absolute poverty ratio increased in 1997 as a result of the economic crisis, reaching 14.28 percent in 1998 before dropling again to 9.84 percent in 2001. A comparison between the absolute poverty ratio and the administrarive povercy ratio (public assistance recipients' ratio) tevealed a considerable gap between the two ratios because of several factors. First, for eligibility the public assistance recipients must satisfy not only the income criteria, which are based on the poverty linc, but also the property criteria, so some of those who qualified by the income criteria might be excluded because their property value exceeded the property criteria. Second, even those who qualify for both incomc and property critcria can be excluobed if they are under the livelihood support of persons legally responsible. If such excluded persons were added into the calculation, the two ratios are likely to be closer to each other.

The economic crisis in 1997 demonstrated weaknesses in the ability of the Korean anti-poverty system to deal with external shocks. The Korean government and ministrics concerned with anti-poverty policies evolved a new model for welfare tailored to the prevailing circumstances of Korea. The changes made to the social protection system reflected the desire to extend benefits to all of society and to update the older system. With such a background, productive Welfare was born in 1999 as a new paradigm of Korean social policy. Productive Welfare is an ideology that seeks to secure minimum living standards for all low-income houscholds, provide human resource development programs to support self-reliance of the poor and guarantee a basic living standard by expanding the coverage of social insurance to all people for the purpose of maintaining human dignity. As such, Productive Welfare endeavors 
to improve the quality of life for all citizens by promoting social development and a fair distribution of wealth. ${ }^{1}$

Table 1. Poverty Ratios (\%)

\begin{tabular}{|c|c|c|}
\hline & Estimated Poverty Ratio & Administrative Poverty Ratio \\
\hline 1975 & $21.52^{! !}$ & - \\
\hline 1980 & $15.25^{11}$ & $4.8^{41}$ \\
\hline 1985 & $18.50^{\mathrm{ji}}$ & $5.6^{4 j}$ \\
\hline 1990 & $15.74^{11}$ & $5.3^{41}$ \\
\hline 1995 & $8.47^{1 !}$ & $3.9^{41}$ \\
\hline 1996 & $7.41^{2 !}$ & $3.3^{4)}$ \\
\hline 1997 & $7.67^{2:}$ & $3.1^{4}$ \\
\hline 1998 & $14.28^{2}$ & $3.2^{43}$ \\
\hline 1999 & $13.67^{3 i}$ & $4.1^{4)}$ \\
\hline 2000 & $10.39^{3}$ & $3.6^{(1)}$ \\
\hline 2001 & $9.84^{j !}$ & - \\
\hline
\end{tabular}

Note: The poverty ratios appeared with superscript numbers 1), 2) or 3), were estimated on the busis of the data from "The Family Income and Expenditure Survey" of the Nitional Statistical Office of Korea, which covered only urban hruseholds, excluding rutal and one-person households.

Source: 1) Park and Kin, 1998; 2) Park, Kim, and Kim, 1999; 3) Park and Kim, 2003; 4) Miniscry of Health and Welfare, Internal Documents.

\section{WELFARE REFORM AND ITS ACHIEVEMENT}

Welfare reform was carried out due to the extremely unstable societal atmosphere, which was caused by the 1997 economic crisis. Hence, whether the reform based on Productive Welfare has helped stabilize the society through protection programs to the poor and the unemployed is the greatest criterion to discuss its achievement. In this dimension, welfare reform can be evaluated as a national management that enabled the society to overcome the difficult situation. According to the concept defined above, introduction of the National Basic Livelihcod Security Act (hercinafter NBLSA) and expansion of the coverage of social insurance are characterized as the projected reform under Productive Welfare. In addition to these are enhancements of the accessibility of the vilnerable class to the labor market through human resource development, which lays stress on labor welfare; measures to protect irregular employees; and extension of the application of a minimum wage system for all industries. Other projected policies based on Productive Welfare such as augmenting cultural and leisure lifestyles for the poor, building a healthy environiment and providing education are

\footnotetext{
${ }^{1}$ Presidential Committee for Quality of Life (1999).
} 
too broad to be argued in this paper. Hence, discussion is narrowed down to policies that are relevant to social security and then examines their achievements and limits.

\section{Public Assistance}

The NBLSA, which started in October 2000 as a replacement for the livelihond Protection Act, guarantees minimum living standards to all low-income families whose income are below the official poverty line without considering their ability to work. So all low-income earners with the ability to work also become eligible for benefits unlike the previous system. The NBLSA puts emphasis on the nation's responsibility for the low-income class. Its introduction has tripled the number of livelihood payment beneficiarics from 540,000 in 1999 to 1.51 million in 2001.23

The official povercy line for the NBISA beneficiaries or recipients is described in Table 2. Those who meet the criteria and do not have any family support will be chosen in the selection. The criteria for those who support the eligible are quite complex. It is limited to immediate fanily members, spouses, and any siblings who are financially supporting them. The supporters are furthermore divided into three groups based on their asset and income: those able to support, those who have difficulty in supporting and those unable to support. Only in the latter two cases are tlueir families cligible for benefit. 4

Table 2. Official Povery I.INe (2001)

\begin{tabular}{|c|c|c|c|c|c|c|c|}
\hline Criteria & One & Two & Three & Four & Five & Six & $\begin{array}{l}\text { Seven \& } \\
\text { More }\end{array}$ \\
\hline $\begin{array}{l}\text { Income } \\
\text { (Thousand Won) }\end{array}$ & 330 & 550 & $7(x)$ & 960 & 1,090 & 1,230 & $\begin{array}{l}\text { Add } 120 \\
\text { per person }\end{array}$ \\
\hline $\begin{array}{c}\text { Property } \\
\text { (Thousand Won) }\end{array}$ & \multicolumn{2}{|c|}{31,000} & \multicolumn{2}{|c|}{34,000} & \multicolumn{3}{|c|}{38,000} \\
\hline
\end{tabular}

Source: Minisrry of Health and Welfare, 2001.

Livilihood payment of the NBLSA is designed to provide supplementary payment to households whose incomes do not meet the official poverty line and the amount of support is cqual to the difference of household income and the official poverty line. Also, civil rights were enhanced through acknowledging the NBLSA as a social

2 Legislated in September 7, 1999 and enacted in Octoter 1, 2000, the NBLSA, which is one of the public assistance programs, has improved che ration's welfare system gratly.

; Park, Ch., Y.M. Kim and T. Kim (2000).

"If the combined income or asset of an applicant's household and his financial supporter's household is wer 120 percent of the income criteria or property criteria of the ufficial poverty line, the supporter under question is regarded as an official supporter. If the applicant is unable to work and has no income, but owns a hause, then the combined income level is raised to over 150 percers of the official poverty line. 
duty. The NBLSA fostered a condition in which the number of Self-Reliance Aid Centers 5 increased from 6 in 1997 to 161 in 2001. The newly introduced NBLS requires the poor with work ability to participate in the self-reliance aid programs. The requirements are judged from the current individual environment of the concerned people with specified conditions for the exemption of the work requirement. At the beginning, while only a small portion of the poor with work ability were taken care of by the Self-Reliance Aid Centers, the principle of conditional benefit provision for the poor wich work ability is expected to bring about a significant result in Korean welfare development. Also, the number of social workets increased from 3,000 persons in 1997 to 5,500 in 2001. Specifically, the increase in the number of Self-Reliance Aid Center participation in self-supporting assistance programs within the community and the inducement of social concerns to the program can be regarded as an achievement. ${ }^{6}$

Nevertheless, the National Basic Livelihood Security (NBLS) system still has toom for improvement. Firstly, the NBLSA was legislated in response to a plea stemming from the bad circumstances of the 1997 economic crisis without a full examination of its implications. For instance, the supplement of officials who are charged with social welfare has not reached its goal and the Ministry of Health and Welfare in charge of the NBLSA has had difficulties in inducing relevant Ministries to collaborate with an investigation into the financial assets of those eligible in the NBLS system and their relatives who have a duty to support. This caused some mis-targeting towards the poor at the beginning of its implementation. It is expected that this problem will remain due to difficulties in surveying incomes of the self-employed. Secondly, the self-support system has not been fully enforced due to a lack of administrative networks with the Ministry of Labor. The self-supporting programs of the Ministry of Health and Welfare have been projected to collaborate with the Ministry of Labor and then, it is pointed out that the official poverty line of selection that is applied equally among all regions (metropolis, medium and small-sized cities, and rural areas) should be resolved? 8

\section{Social Insurance}

The Social insurance system has undergone rapid changes since 1998. The rationality of this change is to drastically reduce uncovered groups through applying the National Pension scheme to all people?; integrate the management systems of the Health Insurance

\footnotetext{
5 The Self Refiance Aid Center was estahlished in 1996 to support recipients of the Luvelihond Procection System (LPS) as well as the low-income eamers who are not covered by the LPS. The main activities of the centet is to provide information on available jobs; to offer job counselling and job placemenc servicts to support the community-based businesses and the self-employed; to mediate the self-reliance fund; and to ceach skills and management rechniques. Self-reliance Aid Centers are sperated by civil groups and designated by the government, but both the central and local governments can party or wholly provide the operating funds (htp://www.mohw go.kr/english/intro8.heml),

"Ministry of Health and Welfare (200)

Park, Ch., Y-M. Kim and T. Kirn (2000).

"Ministry of Labor (2001).

" Major changes broughe by the amendment of the National Pension Act in Januaty 1999 ate as follows.
} 


\section{Funds for Wage Earners (hereinafter HIFW) with the Health Insurance Funds for Non Wage Eamers (hereinafter HIFNW); and expand coverage of Employment Insurance and Industrial Injury Insurance to all workplaces.}

As a result, anyone who has an income is now covered by the National Pension scheme, regardless of employment category, opening an cra of universal National Pension. Now, even if a pension premium is paid only once, pension payment for the disabled and survivors is permitted. ${ }^{10}$ In addition, through integration of management systems of Health lnsurance, it could obtain a ground to raise the social solidarity. 11 Also, as the number of days for which the medical care services can be covered by the Health Insurance has been extended to 360 days, one can get more medical services throughout the year. ${ }^{12} 13$

Hirst, the self-employed in urban areas were included into the scheme begimuing in Aptil 1, 1999. The beneficiaries of the scheme art divided into two groups: wage earners employed by workplaces and local scheme members. Persons insured through the workplace refer tu employees aged between 18 and 60 , who are either emzloyees or employers at a workplace with five or more full rime workers. Those 18 or younger are able to join the workplace pension plan with employer consent. Thase 60 or older can have the excended contribution perind to age 65 if their insured period is less that 20 years. Hinwever, excluded from the coverage of the National Pension Scheme for the workplace are those who have temporary work with concracts of three months or less, thuse whe have scalsunal work with periods of three months or less, and those who often move from workplace to workplace. Temporary and part-time workers are also excluded from coverage of the National Pension Scheme. But those who are excluded from coverage of the National Pcosion Scheme for the workplace are nevertheless instired through the local scheme of the National Pension (Park, Ch. et al. 2000).

10 The new Viational Perision scheme strengthened pensioners rights and soughe for livelihood stability. The minimum contribution period was shortened from 15 years to 10 years. Pension installment is provided for those who tum 60 after divotec or those who divorce after 60 in case marriage has lasted for five years or more (wirh benefit provision reminaring at the time of remarriage). Defered payment for pension contribution atrears is permitted for those obligated with child rearing and military service, as well as for seudentes and those setving prison ternus. Legislation is leing formulated to provide loans to the inemployed for livelihood stability (Park, Ch. et al. 2000).

: Since the introduction of Health Insurance ia 1977, it has goue through sevcral phases before rraturing into a universal Health Insurance scheme due to its inhetent problems. Specifically, Health Insurance Funds did not have the same premium calculation systems. As a result, the insured could have ended up paying different premiums if they belonged wo differets IIealuh Insurance Funds, although their income and asset levels were the same. This caused equity problems and at the same time widened the cinancial gap among Health insurance. Funds. The indegendenr management of smali-size Funds ialso brought lip operational ineffeciency when the Health insurance system was divided into Healsh Insurance Corporations for Employecs of Governenent, Private School, Military, IHIFW, and IIIFNW, To resolve the problems, the government consolidared the HIFN'W and Health Insurance. Corporations for Employees of Government and Private Schools. It was the first stef towards the grand consolidatiun of Health Insurance caken on Octobet 1998. As the second step, the plan integrated I IIF-W/E into che already cansedidated comprehensive Health Insurance Funds, to be the National Healch Insurance Corporation. The new univcrsal Health Insurance Corputation has the integratcd management system for the insured but classifies them inso two groups: HIFW and HIFNW. Those, who are covered by HIFW conssst of employees and employers at the workplace with five or suore people and employees of government and private schools who earn monthly wages. Those who are covered by HIFNW consist of the self-employed and employees at the workplace with four or less people. The new systen: applies the same premium rates in line with income level, regardless of which Health Ynsurance Funds are in charge of the coverage. The new lealth lasurance system has shifted its focus from treatment-orientation to prevention, rehabjlitation and healch promotion (Park, Ch. et al. 2000).

12 The Health Insurance system abolished the regulation of limiting the perind covered by Health Insurance to a certain level. Instead it promises unlimited Healrh lisurance coverage yeat-round beginning July 1, 2000. Previous Health Insurance laws covered only disease, injury, and death excluding pre-natal care from coverage. The new Health Insurance expanded the scope of coverage to inciude preventive care, diaguosis, rehabilitation, health pronotion, not to mention treatrieut and jeath (Park, (h. et al. 2000).

${ }^{13} \mathrm{Kim}_{1}$ Y-M. (1997b). 
Since the 1997 economic crisis, economic recession and dramatic restructuring accelcrated the unemployment rate. Accordingly, the expansion of Employment Insurance coverage was applied earlier than previously planned, beginning March 1998, in order to provide unemployment benefits even to workers at the workplace with five or more persons. Considering the severe unemployment situation, the coverage scope was expanded again in October 1998, to include those at workplaces with four or less persons as well as temporary or part-time workers. ${ }^{14}$ As fot Industrial Injury Insurance, 15 membership has become mandatory even for workplaces hiring less than five persons beginning July 2000. Expanded implementation of social insurance by reduction of the mandatory employment period was geared towards expanding coverage to include temporary and daily workers. ${ }^{16}$

Under the National Pension scheme, temporary, daily, and other part-time employees are classified as local participants. ${ }^{17}$ As for Health Insurance, since July 2001 , temporary and daily workers were transferred to the workplace participant group. Lpon the initial enactment, Employment Insurance was not applied to those who work for less than a three-rmonth period and less than 30.8 hours a week. Since October 1998 , the mandatory employment period was shortened to include those who work more than one month and more than 80 hours per month (or more than 18 hours a week). Recent changes in regulations regarding expanded coverage of employment insurance by shortening the mandatory work period are described in Table 4.

it Since its introduction and implementation in 1995 , Employment Insurance has become the primary social safecy nee for the unemployed during the cconomic crisis when the jobless rate surged. The number of recipients of Employment Insurance was estimated at 50,000 throughout 1997, but in 1998, the number surged to 438,000 . Unemployment benefit provision also skjtocketed to 799.1 billion Won, ten times that of 1997 ' 78.7 hillion Won. Likewise, the sliap inctease in tic number of beneficiaries for 1998 is attributable to the expanded scope of coverage; a string of bankruptcies and firm clusures; lay-offs; early retirement; the reduction of the minimum eoverage period; and the implementation of special expanded payments. In the end, the contribution income of 1998 worth 576 billion won was exceeded by unemployment benefiss expenditures worth 799.2 billion won. in other words, the ratio of contriburion income to benefit payment recorded 139 percent. Unemployment bonefit serves the primary social safecy net with extended cuverage scope, eased eligibilicy criteria, extended coverage periot and extended average coverage period. But despite the eased beneficiary standatds, the ratio of unemployment henefit recipients to the total jobless is 10.5 percent, which is significantly fower in comparison to those of advanced nacions such as Japan (27.8 percent, 1992); Germany ( 13.5 percent, 1990); the US (36.0 percent, 1990); and Britain (30.0 percent, 1998) (Ministry of Healch and Welfare 1999).

"Induserial Injury Insurance was the first social insurance to be adopred in Korea. During introduction, its implementation scope was limited to mines or manufacturing factories with 500 or more people. In industrial injury insurance, cmployers are fully liable for the contributions, which is different from veher sucial insurances. The premium per person is determined by muleiplying the premium tate and the toral amount of salaries. lin 1999, a major legal amendment was made to the industrial ifjury insuranie system. The amendment was made to enhance the faimess by setting maximum and minimum coverage limits with the aim to narrow the benefit gap. Thanks to the amendment, new insurance payments were introduced, and more smal] and medium size firms were included into the system, chereby strengthening its role as a social safecy net (Minisrry of labor 1(509).

16 Lee, G. (1999).

National Pension classifies workers berween 18 ancl 60 , ar workjlaces with five or more employers, and daily or temporary workers who work for more than three months, into workplace persion groups. Those between 18 and 60 who are not workplace workers or insured urader the special occupation pension schemes are classified as loxal pension participant groups. Full-time workers employed for three months or less; part-time wotkers at workplaces with five or less workers; workers at workplaces with five or less employees; and the self-emplnyed can join the National Pension bur many of them are believed to be delinquent contributors to the insurance (Park, Ch. Y.M. Kim and T. Kim 2000). 
Table 3. Process of Korea's Suciai Insurance Coverage Expansion: HY YEAR AND GROUP

\begin{tabular}{|c|c|}
\hline National Pension & Health Insurance \\
\hline 1960: Government employees & $\begin{array}{l}\text { 1977: Wage earners at workplace with } 500 \text { or } \\
\text { more people }\end{array}$ \\
\hline 1963: Military pessonnel & 1979: Employees in government, privare school \\
\hline 1975: Private school teachers & and wage earners at workplace with 300 \\
\hline 1977: Private school personnel & or more pcople \\
\hline $\begin{array}{l}\text { 1988: Wage easners at workplace with } 10 \text { or } \\
\text { more people }\end{array}$ & $\begin{array}{l}\text { 1980: Wage earners at workflare with } 300 \text { or } \\
\text { more people }\end{array}$ \\
\hline $\begin{array}{l}\text { 1992: Wage earners at workplace with } 5 \text { or } \\
\text { more people }\end{array}$ & $\begin{array}{l}\text { 1982: Wage earners at workplace with } 16 \text { or } \\
\text { mote people }\end{array}$ \\
\hline 1995: Fishermen and farmers & 1988: Wage earners at workplace with 5 or \\
\hline 1999: Urban residents (nat & $\begin{array}{l}\text { more people and fishermen and farmers } \\
\text { 1989: Uthan residents (national coverage) }\end{array}$ \\
\hline Employment Insurance & Indlustrial Injury Insurance \\
\hline $\begin{array}{l}\text { 1995: Workplace with } 30 \text { or more people } \\
\text { 1998: Workplace with } 10 \text { or more people } \\
\text { 1998: Workplace with } 5 \text { or more people } \\
\text { 1998: Workplace with } 1 \text { or more people }\end{array}$ & $\begin{array}{l}\text { 1964: Workplace with } 500 \text { or more people } \\
\text { 1965: Workplace with } 200 \text { or more people } \\
\text { 1967: Workplace with } 100 \text { or more people } \\
\text { 1969: Workplace with } 50 \text { or more peoplc } \\
\text { 1974: Workplace with } 16 \text { or more people } \\
\text { 1982: Workplace with } 10 \text { or more people } \\
\text { (some with over } 5 \text { people) } \\
\text { 1992: Workplace with } 5 \text { or more people } \\
\text { 2000: Workplace with } 1 \text { or mure people }\end{array}$ \\
\hline
\end{tabular}

Source: Ministry of Health and Welfare: 1963-2001.

Ministry of Jahor, 1990-2001.

Table 4. Rules to Implement SOCial INSURance fOR NON-Ful-Time WORkers (AS OF DECEMBER, 2000)

\begin{tabular}{c|c|r|r|c}
\hline $\begin{array}{c}\text { Classification } \\
\text { Temporary } \\
\text { daily workers }\end{array}$ & Pension Scheme & Health Insurance & $\begin{array}{c}\text { Emplayment } \\
\text { Insurance }\end{array}$ & $\begin{array}{c}\text { Industrial Injury } \\
\text { Insurance }\end{array}$ \\
\hline Part-time workers & $\begin{array}{c}\text { Classified as loxally } \\
\text { insured persons }\end{array}$ & $\begin{array}{c}\text { Classified as locally } \\
\text { insured persons } \begin{array}{c}\text { More than } 80 \text { hours than } 1 \text { month } \\
\text { (18 hours or more } \\
\text { a week) }\end{array}\end{array}$ & Applied \\
\hline
\end{tabular}

Source: Park, Ch., Y-M. Kim and T. Kim, 2000.

Note: 'lemporary and daily workers join as local participant group in National Pension and as non wage carners in Health. Insurance. 
However, there are still difficulties in improving the systems of National Pension and Health Insurance because of the low rate of income assessment carried out for the self-employed. Due to the self-employed often reporting less than their actual income in an effort to pay a low insurance premium, it's not easy to disclose the scale of the problem. In contrast, salary earners pay their full National Pension and Health Insurance premiums by having their premiums deducted at their income source. This may lead to the unfair circumstance in which the self-employed and the salary earners receive the same medical service to the salary earners' discontent, resulting in boycotting payments of social insurance premiums. Resolutions for this problem have not yet been made due to the fact that the Ministry of Health and Welfare does not have the ability to handle the problem. However, the Ministry in charge of the income assessment of the self-employed could find enforcing the income assessment for cffective management of social insurance a great burden. Consequently, a low tate of income assessment of the self-employed has been maintained and resolutions have not been reached up to this point. ${ }^{18}$

Moreover, destabilization of Health Insurance fund has become a core issue these days, which was in fact predicted several years ago. Although increasing Health Insurance premiums is the most viable option, it is not chosen due to the people's resistance. And so the government announced its policy of increasing a government subsidy to support Health Insurance fund overcome this sinuation.

\section{Limits of Welfare System}

Thanks to the reduction of the eligible employment period requirement and the expansion of qualifying workplaces, marginal workers, 19 who are not covered by social insurance, have decreased for the past two to three years. Despite the concentrated cfforts to extend coverage of social insurance, a substantial numbet of persons still do not have access to income maintenance benefits under social insurance.

Figure 1 shows the coverage scope of Korea's social insurance and the marginalized groups from the insurance system. Health Insurance has a wider coverage scope than the National Pension as it has eased limits in terms of age and eligibility conditions. Employment Insurance and Industrial Injury Insurance are basically targeted for employees, but those who are employed at workplaces with four or less employees in the agricultural and fishery industries have been excluded from the insurance benefits. Considering that agricultural or fishery companics with four or less employees are likely to deal with labor-intensive work which may expose workers to more risk of injuries, such workplaces should be covered by the Industrial Injury Insurance.

18 Kwon, M-I. (2000); Noh, I. (1999); Noh, I. and Ice, Y. (2000).

19 Marginal workers in this paper refers to full time workers at workplaces with four or less employees as well as part-cime workers including temporary daily workers. They share in common the facts their employment status is incomplete and also their exclusion from national welfare or company welfare benefits. 
Furthermore, temporary and daily workers employed for one month or less in all industries and those who work less than 18 hours a week are not covered by Employment Insurance. ${ }^{20}$ But as seen above, measures to place marginal workers under the social security system have been implemented. Efforts for the reduction of the qualifying employment period; a decrease in weekly work hours; and expansion of coverage to workplaces with four or less cmployees have already been put into action. Nevertheless, the system is still faced with obstacles in providing coverage for all workers under the social insurance schemes.

The issue of shortfalls in Korea's social insurance scheme has only recently come to surface despite its importance. Korea's social insurance schemes had provided a protective umbrella in favor of salary and wage earners, but it did not do the same for workers at workplaces with four or less employees and the lowest paying temporary contract-based workers. Hence it is essential to figute out the types of uncovered zones existing in the social insurance scheme and thcir impact on the system. It is also necessary to realize that the government's cfforts to expand the coverage of the four social insurance schemes for the past two or three years have not been sufficient to overcome the problem of excluding some from their coverage and to acknowledge that the difficulty should be dealt with on multiple fronts.

The people who are not insured by social security are categorized into two types. The first consists of the cases in which the social security scheme is not applied. The second is when applicants qualifying for benefits are not awarded due payment. In the case of salary and wage earners, they are not covered for the reason that the contract term is too short. Salary and wage earners do not receive their benefits, although they are entitled, when they have intentionally avoided contribution payment ${ }^{21}$ or the lack of administration infrastructure fails to screen for qualifying recipients and provide benefits in a timely manner. In the following part, the measures to those difficultics are addressed.

\footnotetext{
20) Hwang, D. S. $(2000)$.

In July 2000, among the cotal participants $(16,585,390$ persons $)$, there were $10,879,281$ local participants $(5,144,0150$ are free from contribution payment duties). Those who delay their insurance consribution duc co umenpioyment, bankruptcy, and livelihood difficulties and chose who were unable to pay contribut ions due to milicary service, education, and prison sencence amounted to $4,813,000$. Here the problem is the large number of insured persons unable to pay contrilurions. As of April 2000,30 percent of insured persons under the Nationat Pension, or 5.141,000, are unable to pay insurance concriburions due to low income. 85 percert, or 4,375,000, are either unemployed, have their businesses suspended. or are unaccountable with unclear whcreahouts. Amonis those who delay their pension isisurance contributions are the unemployed, economically inactive persons, full-time housewives, and women with no spouses. Under the curtent system, they are allowed tu defer insurance promiun payments. However, there is a group of people who should not be allowed to delay their payment, but ate classified as permissible delayers. These are the high-inconc asset owners who are estimated to rotal atout 200,000 to 300,000 persons (Park Ch., Y-M. Kim and T. Kim 2000)
} 


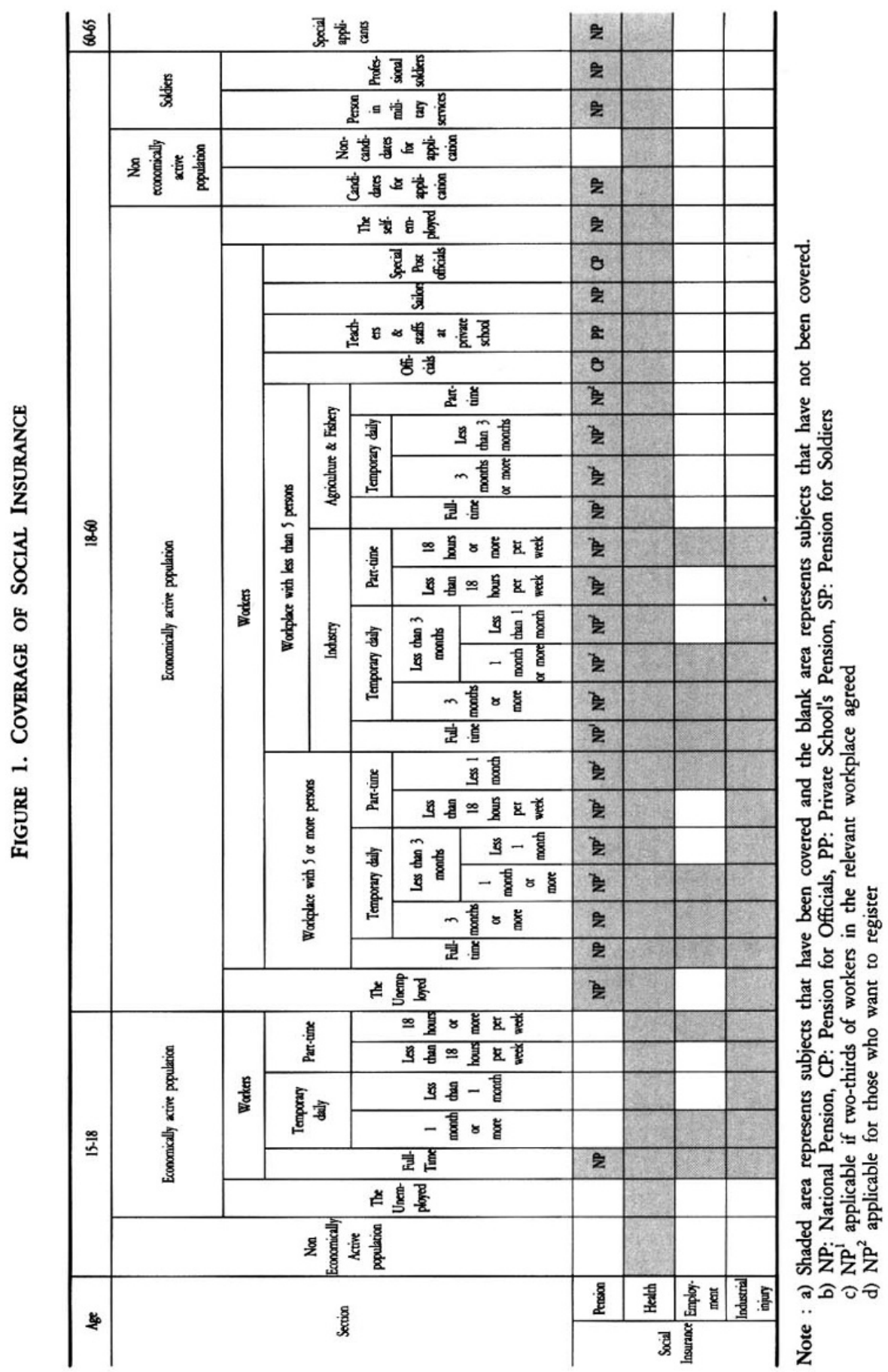




\section{Counter Policies for Improvement}

It is now necessary to set up guiding principles to establish counter policies that arc comprehensive, complete, and fair. In short, this summarizes how the government has pushed to reduce uncovered groups in social security programs. However, the benefit amounts should also reflect reality. Provision of reasonable welfare benefits under the principle of sufficient income support is cssential. For public assistance, an appropriate amount of payments should be guarantecd based on the minimum cost of living. As for the social insurance, the basic rule should be that the insured pay their due contribution and receive corresponding benefits. Even if the uncovered groups are removed and benefit levels are reasonable, the problems in social security programs could remain unresolved if the principle of equality is not applied. Therefore more efforts must be made to apply the rule of equality in selecting beneficiaries and providing fair payments.

\section{Affiliation of Information Systems with Four Social Insurance Management Bodies}

The management of workplaces and insured persons by one administrative body instead of four, can create synergy effects on insurance administration. In particular, by affiliating the channels of qualification management, charging and collecting into one, it is much casicr to check the eligibility for marginal workers; those in workplaces with four or less employees; and also the self-cmployed. That is, under this system, insured persons of one social insurance are immediately recognized as insured under other social insurances, making it less likely for them to be left uncovered. The possibility of applying insurance to marginal workers who are featured by frequent workplace closure and bankruptcy, as well as frequent job changes, depends on whether or not their employment status and wage level can be completely figured out.

For these reasons, countries with a long history of social insurance often opted for consolidated charging and collection of social insurance contributions. For instance, in Germany, pension, employment insurance, and health insurance are charged and collected by the health insurance administrative organization in the form of a comprehensive social insurance premium.

\section{Collection of Insurance Premium by National Tax Authority}

Another way to reduce uncovered groups in social insurance by preventing intentional contribution avoidance is to make social insurance contribution mandatory. In fact, it is often found in many nations that taxes and social insurance contributions are linked or integrated. National tax agencies collect social insurance contributions by including them in taxes and transferring the amount to related social insurance organizations. One of the problems found in applying social insurance to marginal workers is that both employers and insured persons tend to avoid their contribution 
payments. No doubt the national tax authority is in a better position to resolve this problem as it has access to massive data regarding income and assets as well as much stronger authority to charge and collect. Since the National Tax Service of Korea manages all assets, income, and tax payment documents on an individual basis, it is also better poised to transform the social insurance scheme to an individual based management scheme. Also, if employers make false reports regarding wage or employment status, tax authorities are then given the ability to correct the wrong data based on various documents they have secured. The agency involvement would be in an excellent position to check for moral hazards in terms of contribution payment and benefit reception of insured persons and employees (contribution payment avoidance, Falscly scaled-down income reports, and redundant reception of benefits). Beyond that, combining collection of taxes and social insurance payments will boost administrative efficiency and reduce collection costs, thereby bencfiting employers.

This method is adopced by the U.S. (its national tax agency charges and collects social insurance contributions); the U.K. (its national tax agency has taken the responsibility of charging and collecting social insurance contributions beginning in 1999); Sweden; and Argentina. In particular, the consolidation of social insurance payment collection with tax collection in Argentina is regarded as a model case for improvement in managerial and operational efficiency. 2223

\section{Strengthening the Ability to Survey Income of the Self-Employed24}

By strengthening the income assessment level of the self-employed, blind spots in the NBIS, the National Pension and the Health Insurance could be scaled down. Undeclared income and the under-reporting of income for the self-employed are so prevalent that this has become one of the major problems in social security. The reason behind the need for concentrating all efforts into the income assessment of the self-employed is that public assistance, especially determining the financial assets of the family supporters in regards to NBLS and poverty related monitoring function, may not be able to operate properly in cases where the income of the self-employed is not properly surveyed. Such a low rate of accurate income assessment carried out for the self-employed causes huge concern in social insurance as well. However, in the case of Korea, in spite of not having the complete income assessment data, not only is the National Pension being expanded to include the self-employed in the urban area, but the integration of Health Insurance Funds and furthermore financial integration is underway. Basically a society which has difficulty carrying out the income assessment effectively, is consequently lef: to face the challenges in achieving the welfare policies of an advanced society. Moreover, the success of social insurance schemes based on integration and social solidarity is jeopardized. As a result, in order to

32 IIO (2000).

23 Park Ch. Y-M. Kim and T. Kim (2000).

24 National Commitre for Self-employed lncome Assessment (1999). 
uplift the income assessment level, active participation and co-operation from the Ministry of Finance and Economy and National Tax Service are necessary, otherwise it is unavoidable to convert the existing social insurance scheme into another system that can operate even with the low-income assessment.

In 1999, the National Committee for Self-employed Income Asressment recommended various measures designed to resolve the issue of inaccurate declatations of income. In the course of 1999 and 2000, taxation reform executed by the National Taxation Service was put into practice, including several measures to revamp the value added tax system, by accelerating credit card use and restructuring ways to improve relevant income data of the self-employed. This overhaul can be evaluated to set the tone for assessing the accurate income status of the self-employed. It is also expected to play an important role in understanding the employment and wage status of employees at small workplaces, as well as documents on charging contributions for social insurance schemes. A variety of measures to promote credit card use, in particular the credit card lottery scheme, have almost doubled credit card use for the first half of 2000 compared to the same period in 2001. The use of credit cards has been on a steady rise, becoming a significant help in exposing the undeclared income of the self-employed. However, the utilization of these various taxation reforms will take too long to be used as the basis for collecting social insurance contributions. Therefore it would be desirable to carry out tax investigations on a random basis, as observed in many other nations and when a violation is found, stern punishment should be imposed. This measure will boost public awareness that tax evasion is a serious crimc. Only then will it be possible to obtain a better grip on the accurate size of income for the self-employed, during a relatively short perind of time.2s

\section{Optimizing the Level of Social Security Benefits}

Even if income maintenance is applied and the minimum insured period is met, these benefits cannot provide full protection against risks if the social security benefit level is too low. The level of NBLS payment was set based on the research on the minimum cost of living by the Korea Institute for Health and Social Affairs (KIHASA). The minimum cost of living measured by KIHASA goes through a thorough review by the Central Minimum Living Standard Committet which consists of government officials, scholars, labor unions and NGOs. Therefore, the level of NBLS payment has been estimated to be appropriate for the current situation.

Under Industrial Injury Insurance, the cash benefits have met the international level set by the International Labour Organization, except for rehabilitation and medical services.26 Joh seeking benefits under Employment Insurance were pointed out to be less than it should be and therefore recent policics have been introduced to boost the benefits (beginning January 2000, benefit provision period was increased from

\footnotetext{
25 National Tax Scrvice (200(0)a ; National Tax Service $\{2000 \mathrm{~b}$.

26 Kim, Y-M. (1997a).
} 
60-210 days to 90-240 days and minirnum job seeking benefits have been pulled up from 70 percent to 90 percent). This means that as long as they are entitled for coverage, the marginal workforce will find it more beneficial. In the case of Heatth Insurance, it has been estimated that it provides relatively low benefits and no disease or injury cash benefits. As for National Pension, it is designed that those insured with shorter contribution periods receive smaller pensions. Therefore the marginal workforce whose insured period is relatively short may appeat to face disadvantages. However, given the fact that National Pension is designed for income redistribution, from which the low-income class can benefit the most, 27 the marginal workforce and employees belonging to small workplaces and earning less income are not in a disadvantageous situation.

Benefit levels under social insurance proportional to contribution levels and contributory periods are commonly found. It has limited ability to adjust benefit levels and contriburory periods as long as the social insurance scheme is being operated within the insurance framework. In a relaced move, the issue of increasing benefit levels and benefit provision periods should be discussed in line with the mounting burden of contribution payments and government support. In the case of the marginal workforce and employees at small workplaces, they could be entitled to government support in paying contributions.

\section{CONCLUSIVE REMARKS}

It was only as recent as three to four years ago, that the general public began to regard the welfare scheme as being substantial to their daily life. This is because the welfare scheme has been applied mainly for the poor not being able to work or for workers employed in big companies, excluding often the self-employed or the poor with working ability. However, the 1997 economic crisis made the Korean government speed up its response to the surging unemployment rate and poverty ratio. It was an incident, which prompted the government to declare Productive Welfare as one of the fundamental governing principles in parallel with Democracy and Market Economy. The efforts to strengthen the social security system allowed it to take another leap forward. However, inherent problems have appeared in the course of trying to develop social welfare systems within a short time frame, which have taken advanced nations several decades. As a result, blind spots in social security coverage and the lack of effective links among systems have become downsides of the process.

This paper presented a comprehensive review of the social security system including major public assistance programs and social insurance schemes. It also discussed the counter measures to scale down blind spors in social security coverage. As discussed in this paper, Korea's social security has developed based on the two pillars of social

Kwon, M-I. (2000). 
insurance and public assistance. Despite problems arising in the process of evolution, Korea's Health. Insurance system is cited as one of the most successful social security systems for developing nations. Therefore, assuming that these issues can be resolved through revision and reform of the existing scheme, this study focuses on exploring ways to create an environment where functions of the existing social security scheme can be improved. Additionally, ways to resolve defects in the system were also reviewed.

As a result, the following conclusion has been made. Measures to scale down blind spots in social security coverage boils down to dealing with the marginal workers. Their exclusion from social insurance coverage is cited as a major shortcoming of Korea's social insurance, along with inaccurate assessment of income for the self-employe d.28 The problem also stems from the combination of characteristics of the economic structure (size of the black market); contribution rates of social insurance by employers and employecs (rate of contribution avoidance); income level of insured persons; level of taxation administration; managerial capability of social insurance administration; and others. Nonetheless as the National Tax Service adopts the function of both determining recipient eligibility and charging contribution, the managerial capacity of social insurance will be strengthened. This change will serve as a breakthrough in consolidating social insurance funds and making social insurance expansion mote effective. In the future, administrative organizations for social security systems need to improve benefit service provision to boost social credibility and ease the burden stemming from standard control of beneficiary criteria, as well as the charging and collecting of contributions. For these matters, related government authorities and social insurance officials are required to take a more creative approach.

\section{REFERENCES}

Hwang, D. S. 2000. Changes in Linemployment Benefits and Management System of the Insured following the Extension of the Unemployment Insurance Coverage (in Korean). Seoul: Korea Labor Institute.

ILO. 1989. Intmatuction to Social Security. 3rd ed. Geneva.

ILO. 2000. World Labour Report: Income Security and Sacial Protection in a Changing World. Geneva.

Kim, Y-M. 1997a. Application Procedure of Korea Social Insurance and lnequality (in Korean). Korea Sorial Welfare and Inequality. Seoul: Study Center of Social Welfare. Kim, Y-M. 1997b. Standards of ILO's Social Security and Problems of Improving Korea Social Security (in Korean). Korea Joumal of Social Welfare, 31. Scoul: Academic Society of Social Welfare.

\footnotetext{
28 Accurate assessment of income for the self-employed will determine success of Korea's soxial insurance scheme as well as the ability to cover employed persons with social insutance schemes. Although this seemed impossible even two to three years ago, it is now possible oot only to figure out the income size of self-employed persons but also to accurately assess the income and employment status of emplovees at workplaces run by self employed persons.
} 
Kown, M-I. 2000. Profit Survey of National Pension: Is the National Pension Payment a fair profit for an Insurance Bill? (in Korean) Korea Joumal of Social Welfare, 41. Seoul: Academic Society of Social Welfare.

Lee, G. 1999. Problems of Korea Work Injury Insurance and Guide for its Improvement (in Korean). Joumal of Social Welfare Policy, 9. Seoul: Academic Society of Korea Social Welfare Policy.

Ministry of Heaith and Welfare. 1963-2001. White Paper (in Korean). Seoul.

Ministry of Labor. 1990-2001. White Paper (in Korean). Seoul.

National Commitcee for Self-employed Income Assessment. 1999. Policy Proposal for the Selfemployed Income Assessment (in Korean). Seoul.

National Tax Service. 2000a. Announcement of Madifying a Value Added Taxation System (in Korean). Seoul.

National Tax Service. 2000b. Six-mosth Operation of Cnedit Card Reieipt Lattery System (in Korean). Seoul.

Noh, I. 1999. Self-employed Income Assessment and Levy System of Insurance (in Korean). Joumal of Social Welfare Policy, 9. Seoul; Academic Society of Korea Social Welfare Policy.

Noh, I. and Y. Lec. 2000. Evaluation of A Year Extension of National Pension into Urban Areas and Guide for its Improvement (in Korean). Materials for Seminar on Evaluation of A Year Extension of National Pension into Urban Areas and Guide for its Improvement. National Pension Corporation.

Park, Ch. 2003. Analysis on Rediseributive Effect of Transfer Income and Direct Tax in Korea (in Korean). Korean Journal of Public Economics, 18 (1).

Park, Ch. and T. Kim. 2003. Change in Poverty After the 1997 Economic Crisis (in Korean). Mimeo.

Park, Ch, G. Kim and T. Kim. 1999. The Cbange in Powerty and Income Inequality Level during Economic Crisis and Counter Policies in Korea (in Korean). Seoul: KIHASA.

Park, Ch. and G. Kim. 2000 Poverty Measurement by Characteristics of Household Head during the Economic Crisis (in Korean). Korean Sacial Security Studies, 16 (1).

Park, Ch. and M. Kim. 1998. Current Poverty Issues and Caunter Policies in Korea (in Korean). Seoul: KIHASA-UNDP.

Park, Ch., Y-M. Kim and T. Kim. 2000. Schemes for Reforming Korean Income Maintenance System to Expand the Social Safety Nets (in Korean). Seoul: Korea Institute for Health and Social Affairs.

Presidential Committee for Quality of Life. 1999. Df Welfarism. Seoul: Office of the President of Korea. 